Whereas, our democratic government rests on informal public debate and deliberations by policymakers based on access to the fullest possible records of the past and on an accurate presentation of our history; and

Whereas, various agencies of the United States government are urging foreign governments to open their archival records, it is essential that the United States follow a standard worthy of emulation; and

Whereas, the role of the State Department's Advisory Committee on Historical Diplomatic Documentation, made up of the representatives of the American Political Science Association, the American Historical Association, the Organization of American Historians, the American Society of International Law, and the Society for Historians of American Foreign Rela-

tions, is now threatened as they are no longer informed participants in the review process and are no longer in a position to attest to the integrity of the series;

Resolved, the American Political Science Association urges Secretary of State James Baker to take necessary steps to restore the integrity of the Foreign Relations of the United States by establishing a procedure by which the Advisory Committee, who have "secret" clearances, may review the necessary materials in order to make informed judgments on the integrity of the series.

Hauck also reported on the APSA's 1990 competition for small grants.

18. Catherine E. Rudder reported on how the Association has been expanding its programs to recruit minority political scientists. The long established program to identify Black fellows drew 87 applicants this past year. Twenty-five fellows were selected. The Ralph Bunche Summer Institute moved to Atlanta where it was conducted very well. In addition, Louisiana State University hosted a special reunion of Bunche alumni. There is interest, particularly on the part of Arizona State University, in developing a comparable institute for Latino students. There is considerable participation in the minority identification project, instituted this past year. In addition, the Association is developing a new special masters degree program to recruit and train minority students. Council members asked the Association to explore:

a. opportunities of direct funding to the declining pool of black professors, and

b. increasing the number of minority graduate students receiving support by stretching the available funds.
19. David Brady reported on the Association's budget for 1989-90 and the budget estimated for 1990-91. The Council approved the budgets unanimously. The Council also received the Audit Report and the report on the status of the Trust and Development Fund.

The Council agreed to an increase in the Annual Meeting registration fees, effective in 1991, noting that inflation has eroded the value of the fee since it was set five years ago and that APSA registration will still be lower than that of most other social science associations. The new fee structure will be:

$\begin{array}{lcc} & \begin{array}{c}\text { Pre- } \\ \text { Registration }\end{array} & \begin{array}{c}\text { Registration } \\ \text { Student Member }\end{array} \\ \$ 20.00 & \$ 25.00 \\ \text { Regular Member } & \$ 45.00 & \$ 60.00 \\ \text { Non-Member } & \$ 75.00 & \$ 95.00\end{array}$

20. The Council received a report on the APSA and Pi Sigma Alpha Oral History Project, supported by a three-year authorization from APSA. The Council agreed the annual contribution would be $\$ 5,000$ with half of the APSA funds coming from the Kirkpatrick Fund.

21. Catherine E. Rudder alerted the Council to possible restrictions on grant content in the reauthorizing statute for the National Endowment for the Humanities. Such restrictions, which would be comparable to those imposed on the National Endowment for the Arts, could well impede faculty acceptance of NEH support.

22. Catherine E. Rudder discussed the report of the Coalition for the Advancement of Foreign Languages and International Studies (CAFLIS). Concerns were expressed about the procedure for the preparation of the Council's report and the language adopted to signify Association endorsement. Nonetheless, Council members approved continuing APSA membership in CAFLIS.

23. Samuel Patterson could not attend the Council meeting to report on the APSR. Council members agreed to invite Bingham Powell, the newly appointed editor, to the spring 1991 Council meeting to discuss issues regarding access to publication in the Review by research subfields that have been underrepresented, e.g., comparative politics, women and politics.

24. The Council reviewed and approved the Administrative Committee's response to a request from the Gay and Lesbian Caucus regarding the selection of sites for future annual meetings. The Council adopted a nonbinding resolution calling for the APSA national office to make a good faith effort to locate the convention in cities without statutes that are hostile or restrictive to Gays. The objective is to secure the comfort of all members who attend an Annual Meeting.

25. Theodore Lowi announced that the next Council meeting will be on Saturday, April 20, in Chicago, in conjunction with the Midwest PSA Annual Meeting.

26. The Council completed discussion of issues on its agenda and turned to the proposals raised in letters from Mansbridge and Lawson regarding members' assessment of the APSA and increasing their involvement in its activities and policies. Suggestions ware made to use $P S$ to discuss issues that do not go to the Council and to distribute a questionnaire to evaluate the Annual Meeting. Council members differed on whether to actively encourage controversy as a means of engaging members, i.e., to establish contested elections for officers. Theodore Lowi pointed out that the Association should support members' pursuit of their research and professional commitments at their universities and colleges; and that members should be encouraged to nominate themselves for roles in the Association. Sandy Maisel noted that the search for conflict, when none exists, is an artifice. Crawford Young expressed support for contested elections. Kay Lawson maintained that many political scientists may be alienated and feel left out of the activities of the Association. The Council agreed to decide, at its next meeting, whether there should be a committee to examine the question of membership participation.

27. The Council went into Executive Session.

\section{Committees of the American Political Science Association}

\section{Constitutional Committees}

\section{Administrative Committee}

The Administrative Committee consists of the president, president-elect, treasurer and four other Council members whose main duties include preparing agendas for Council meetings and annual business meetings and acting on behalf of the Council to dispose of policy issues deemed of insufficient weight to require decisions by the Council.

David Brady, Stanford University

William J. Daniels, Rochester Institute of Technology

Jean Bethke Elshtain, Vanderbilt University

Virginia H. Gray, University of

Minnesota

Theodore J. Lowi, Cornell University 
Sandy Maisel, Colby College

James Q. Wilson, University of

California, Los Angeles

\section{Nominating Committee}

The Nominating Committee selects one nomination for each elective office to be filled and submits the slate for the next annual business meeting, with a report to the president no later than April 15.

Terms expiring December 31, 1992:

Benjamin Ginsberg, Cornell University, chair

Paula D. McClain, Arizona State University

Donald Robinson, Smith College

Terms expiring December 31, 1991:

Stephen Holmes, University of Chicago

Robert Keohane, Harvard University

Kay Schlozman, Boston College

\section{Program Committee}

Program Committee members are appointed by the Council after it hears the recommendations of the Program Chair-Designate. Members organize all panels, plenary sessions, and other aspects of the official program for the annual meeting.

George Quester, University of

Maryland, chair

Robert J. Art, Brandeis University

Robert H. Bates, Duke University

Theodore Becker, Auburn University

G. R. Boynton, University of Iowa

John Brigham, Syracuse University

Gary Bryner, Brigham Young University

Susan J. Carroll, Rutgers University

Fred Dallmayr, University of Notre Dame

Richard Flathman, Johns Hopkins

University

Christopher H. Foreman, Jr., Brookings Institution

Charles H. Franklin, Washington

University

G. David Garson, North Carolina State University

Judith Goldstein, Stanford University

Leslie F. Goldstein, University of Delaware

Victoria Hattam, Yale University

Rodney Hero, University of ColoradoBoulder

Bruce W. Jentleson, UC-Davis, Washington Center

Gary R. Johnson, Lake Superior State University

Ruth S. Jones, Arizona State University

Dennis Judd, University of Missouri, St. Louis

Joyce Kaufman, Whittier College

John Kincaid, U.S. Advisory Commission on Intergovernmental Relations

David Laitin, University of Chicago

David A. Lake, University of California, Los Angeles
David C. Leege, University of Notre Dame

Robert L. Lineberry, University of Houston

Gale A. Mattox, U.S. Naval Academy

Lawrence C. Mayer, Texas Tech University

Michael Nelson, Vanderbilt University

Joe Oppenheimer, University of Maryland

M. J. Peterson, University of Massachusetts

Karen Rasler, University of California, Riverside

Jorgen Rasmussen, Iowa State University

Wilma Rule, University of Nevada

Martin A. Schain, New York University

Lee Sigelman, University of Arizona

Howard Silver, Consortium of Social Science Associations

William R. Thompson, University of California, Riverside

Carole J. Uhlaner, University of California, Irvine

Paul Viotti, U.S. Air Force Academy

Hanes Walton, Savannah State College

Mark Warren, Georgetown University

Ronald E. Weber, University of Wisconsin, Milwaukee

Susan L. Woodward, Brookings Institution

Betty Zisk, Boston University

\section{Trust and Development}

Board of Trustees

The Trust and Development Fund Board of Trustees consists of the treasurer of the Association, who serves exofficio as chair, and six other trustees who direct the investment of the Fund's resources.

Terms expiring December 31, 1993:

Warren Miller, Arizona State University Inez Smith Reid, Washington, D.C.

Terms expiring December 31, 1992:

William Keefe, University of Pittsburgh

Jack Peltason, University of California, Irvine

Terms expiring December 31, 1991:

Leon Epstein, University of Wisconsin, Madison

Donald Stokes, Princeton University

\section{COUNCIL COMMITTEES}

\section{Elections Committee}

Three members are appointed after the election from among newly elected and continuing Council members. The committee supervises the conduct of Association elections.

Gregory Caldeira, Ohio State University Judith Stiehm, Florida International University, chair

Ronald Walters, Howard University

\section{Rules Committee}

Three members are appointed after the election from among newly elected and continuing Council members. The committee reviews the Association's By-Laws and Rules of Procedure for governing the conduct of the annual business meeting and proposes revisions as they are deemed necessary.

Rodolfo O. de la Garza, University of Texas, Austin, chair

Nolan Jones, National Governors'

Association

Michael Lipsky, Massachusetts Institute of Technology

\section{Organized Sections Committee}

Three members are appointed after the election from among newly elected and continuing Council members. This committee was established to recommend action on petitions to establish sections, monitor section activities, advise the staff on administrative arrangements for sections, and conduct an ongoing review of sections.

Charles Bullock, University of Georgia Thomas Cronin, Colorado College, chair Ruth S. Jones, Arizona State University

\section{COUNCIL AUTHORIZED COMMITTEES AND SPECIAL PURPOSE COMMITTEES}

\section{Congressional Fellowship Program Advisory Committee}

The Congressional Fellowship Program Advisory Committee provides overall guidance for the program.

David S. Broder, The Washington Post

Robert Dole, U.S. Senate

Thomas S. Foley, U.S. House of Representatives

Bill Frenzel, U.S. House of

Representatives

David R. Gergen, U.S. News and World Report

James F. Hoge, Jr., New York Daily News

Albert R. Hunt, The Wall Street Journal

Richard G. Lugar, U.S. Senate

Thomas E. Mann, Brookings Institution, chair

Philip Meyer, University of North

Carolina

Norman J. Ornstein, American Enterprise Institute

Leonard Parkinson, Atlantic Research Corporation

Honorable Richardson Preyer, Greensboro, North Carolina

David E. Price, U.S. House of

Representatives

Cokie Roberts, National Public Radio

Robert M. Rosenzweig, Association of 
American Universities

Paul Simon, U.S. Senate

Barbara Sinclair, University of

California, Riverside

Neil Skene, Congressional Quarterly

Charls E. Walker, Charls E. Walker Associates, Inc.

Eddie N. Williams, Joint Center for Political Studies

\section{Committee on Departmental Services}

The Committee on Departmental Services advises on publications and other services for members of the Association's Departmental Services Program.

Terms expiring December 31, 1993.

Natalie Davis, Birmingham-Southern College

Frank L. Wilson, Purdue University, chair

Terms expiring December 31, 1992:

Michael Maggiotto, Bowling Green State University

Bruce I. Oppenheimer, University of Houston

Term expiring December 31, 1991:

Susan Sullivan, National Cathedral School

\section{Editorial Board, $P S$}

The Editorial Board, $P S$, consists of five members who advise the editor on the content of each issue.

Terms expiring December 31, 1993: Doris Graber, University of Illinois at Chicago

Stephen Newman, York University

Terms expiring December 31, 1992:

Elliot Cohen, School of Advanced International Studies, Johns Hopkins University

Margaret Galey, Washington, D.C.

Term expiring December 31, 1991:

Peter Zwick, California State University, San Marcos, chair

\section{Editorial Board of the TEACHER}

The Editorial Board, the Political Science Teacher, consists of five members who advise the editor on the content of each issue.

Term expiring December 31, 1993:

Eleanor Main, Emory University

Terms expiring December 31, 1992: Aaron Friedberg, Princeton University Melanie N. Jackson, Southern University

Terms expiring December 31, 1991:

Betty Phillips, Northern Virginia

Community College

Donald Racheter, Central College

\section{Committee on Publications}

The Committee on Publications has five members, in addition to ex-officio members. The Committee oversees and coordinates existing APSA publications, explores possible relationships with political science journals not sponsored by the Association, and develops proposals for new publications, when appropriate.

Terms expiring December 31, 1993:

Donald Kettl, University of Wisconsin

Dean Mann, University of California, Santa Barbara

Terms expiring December 31, 1992:

Richard Betts, Brookings Institution

Karen Feste, University of Denver

Term expiring December 31, 1991:

Micheal Giles, Emory University, chair

Ex-officio:

Peter Zwick, California State University, San Marcos (PS)

Samuel C. Patterson, Ohio State University $(A P S R)$

\section{Committee on Education}

The Committee on Education consists of five members who develop, coordinate and review educational programs and activities following guidelines outlined by the Council.

Term expiring December 31, 1993: Wilbur Rich, Wayne State University

Terms expiring December 31, 1992:

Mary Hepburn, University of Georgia

Tracy Strong, University of California, San Diego

Terms expiring December 31, 1991:

Richard Brody, Stanford University, chair

Edward Thompson, University of California, Davis

\section{Kirkpatrick Fund Board of Trustees}

The Evron M. Kirkpatrick Fund was established to aid in the study of political science as a discipline and profession and to pay tribute to Dr. Kirkpatrick's distinguished service of 27 years as executive director of the APSA. The Board is responsible for overseeing the endowment of the Fund and setting policy guidelines for the administration of the Fund's programs, which presently include the Oral History Project housed at the University of Kentucky and a monograph series on the craft of political science.

Terms expiring December 31, 1993: Martha Kumar, Towson State University

Frank Sorauf, University of Minnesota, chair

Terms expiring December 31, 1992:

Milton Cummings, Johns Hopkins University

Robert Faulkner, Boston College
Terms expiring December 31, 1991:

E. Wally Miles, San Diego State

University

Robert Scalapino, University of

California, Berkeley

\section{Committee on International}

Political Science

This committee was created by the Council to develop relationships between American political science and political science in other nations. It oversees bilateral exchanges (currently with the Chinese Association of Political Science in Beijing and with the USSR Academy of Sciences and the Soviet Political Science Association), the proposed South African Fellowship Program, the Foreign Student Travel Grants to APSA's annual meeting, the selection of travel fellows of the American Council of Learned Societies, the APSA's relationship with the International Political Science Association and other non-U.S. national and international associations.

Terms expiring December 31, 1993:

Lily Gardner Feldman, American Institute for Contemporary German Studies

Marie-France Toinet, Fondation Nationale des Sciences Politiques

Term expiring December 31, 1992: Peter Katzenstein, Cornell University

Terms expiring December 31, 1991:

Evron M. Kirkpatrick, Heldref Publications

Robert E. Ward, Stanford University, chair

Committee on Professional Ethics, Rights and Freedoms

The Committee on Professional Ethics, Rights and Freedoms' responsibility is to protect the rights of political scientists and ensure that the ethical policies of the Association are followed.

Terms expiring December 31, 1993.

Seyom Brown, Brandeis University

Armin Rosencranz, San Francisco State University

Term expiring December 31, 1992:

E. Wally Miles, San Diego State University

Terms expiring December 31, 1991:

Gayle Binion, University of California,

Santa Barbara, chair

Paul Beck, Ohio State University

\section{Research Support Committee}

The Research Support Committee oversees activities regarding public and private research support for political scientists.

Term expiring December 31, 1993: 
F. Chris Garcia, University of New Mexico

Terms expiring December 31, 1992: Gary Jacobson, University of California, San Diego, chair

Timothy Tilton, Indiana University

Terms expiring December 31, 1991: Donna Bahry, New York University David Brady, Stanford University

Roy Grow, Carleton College

Committee on the Status of Blacks in the Profession

The Committee on the Status of Blacks in the Profession develops and promotes activities concerning the professional development of blacks within the discipline.

Terms expiring December 31, 1993 :

Sheila Ards, University of Maryland

Charles P. Henry, University of

California, Berkeley

Term expiring December 31, 1992:

Christopher H. Foreman, Brookings Institution

Terms expiring December 31, 1991: Cheryl Brown, University of North Carolina-Charlotte

Mitchell Rice, Louisiana State University, chair

\section{Committee on the Status of Latinos in the Profession}

The Committee on the Status of Latinos in the Profession develops and promotes activities concerning the professional development of Latinos within the discipline.

Terms expiring December 31, 1993: Fernando Guerra, Loyola Marymount University

David Olson, University of Washington

Maria Torres, DePaul University

Term expiring December 31, 1992:

David Mares, University of California,

San Diego, chair

Terms expiring December 31, 1991:

Dario Moreno, Florida International University

James Regalado, California State

University, Los Angeles

\section{Committee on the Status of Women in the Profession}

The Committee on the Status of Women in the Profession develops and promotes activities concerning the professional development of women within the discipline.

Terms expiring December 31, 1993:

Jane Jaquette, Occidental College
Marian L. Palley, University of ·

Delaware, chair

Term expiring December 31, 1992:

Mary Katzenstein, Cornell University

Terms expiring December 31, 1991:

Sue Tolleson Rinehart, Texas Tech University

Rosemarie Rogers, Tufts University

\section{Development Committee}

This committee was authorized by the Council in 1988 to propose development goals and policies to the Council and oversee their eventual implementation.

Terms expiring December 31, 1993:

Luis R. Fraga, University of Notre Dame

Helen Ingram, University of Arizona

Terms expiring December 31, 1992:

Austin Ranney, University of California, Berkeley

Robert M. Rosenzweig, Association of American Universities, chair

Terms expiring December 31, 1991:

Roberta Sigal, Rutgers University

Kenneth Waltz, University of California, Berkeley

\section{Advisory Committee for the APSA/} Pi Sigma Alpha Oral History Program

This committee was jointly appointed in 1987 by APSA and Pi Sigma Alpha for a three-year term to give overall policy direction for the Oral History Project which is being processed, archived and disseminated by the University of Kentucky with Malcolm Jewell as Project Director.

Karl Cerny, Georgetown University, chair

William Daniels, Union College

Robert Huckshorn, Florida Atlantic University

Virginia Sapiro, University of Wisconsin

Ray Seidelman, Sarah Lawrence College

\section{Charter Review Committee}

\section{for Ethics Committee}

The Council asked that this committee be appointed to review the charge to the Committee on Professional Ethics, Rights and Freedoms.

Gayle Binion, University of California, Santa Barbara

Lawrence Herson, Ohio State University, chair

John Wahlke, University of Arizona

Nancy Zingale, College of St. Thomas

\section{AWARD COMMITTEES}

\section{Gabriel A. Almond Award- $\$ 250$}

This award is given each year for the best doctoral dissertation completed and accepted that year or the previous one in the field of comparative politics.

Rodolfo O. de la Garza, University of

Texas, Austin

Cynthia Enloe, Clark University

Sidney Tarrow, Cornell University, chair

William Anderson Award- $\$ 250$

This award is given each year for the best doctoral dissertation completed and accepted that year or the previous one in the field of state and local politics, federalism or intergovernmental relations.

William Nelson, Ohio State University Jeanie R. Stanley, University of Texas, Tyler, chair

Richard Wilson, University of

Tennessee, Chattanooga

\section{Edward S. Corwin Award-\$250}

This award is for the best doctoral dissertation completed and accepted during that year or the previous year in the field of public law, broadly defined to include the judicial process, judicial behavior, judicial biography, courts, law, legal systems, the American constitutional system, civil liberties, or any other substantial area, or any work which deals in a significant fashion with a topic related to or having substantial impact on the American Constitution.

Dean Alfange, University of

Massachusetts

Abraham Davis, Spelman College

Dorothy Marie Provine, Syracuse

University, chair

\section{Harold D. Lasswell Award--\$250}

This award is for the best doctoral dissertation completed and accepted during that year or the previous year in the field of policy studies and is supported by the Policy Studies Organization.

Elizabeth Sanders, New School for Social Research

Bruce Smith, Brookings Institution, chair Norman Thomas, University of Cincinnati

\section{Helen Dwight Reid Award - $\$ 500$}

This award is for the best doctoral dissertation completed and accepted during that year or the previous year in the field of international relations, law and politics.

Matthew Evangelista, University of Michigan, chair

Catherine Kelleher, Brookings Institution John Wilson Lewis, Stanford University

\section{E. E. Schattschneider Award- $\$ 250$}

This award is for the best doctoral dissertation completed and accepted during 
that year or the previous year in the field of American government.

Michael Goldfield, Cornell University

Karren Orren, University of California, Los Angeles, chair

Jerry G. Watts, Trinity College (CT)

\section{Leo Strauss Award- $\$ 250$}

This award is for the best doctoral dissertation completed and accepted during that year or the previous year in the field of political philosophy.

James S. Fishkin, University of Texas at Austin

Nancy S. Love, Pennsylvania State University, chair

Hanna Pitkin, University of California, Berkeley

\section{Leonard D. White Award- $\$ 250$}

This award is for the best doctoral dissertation completed in that year or the previous year in the general field of public administration, including broadly related problems of policy formation and administrative theory.

Candace Hetzner, Rutgers University, Newark

Roger Marz, Oakland University

David Rosenbloom, American University, chair

Franklin L. Burdette

Pi Sigma Alpha Award- $\$ 250$

This award is for the best paper presented at the previous annual meeting.

Liane C. Kosaki, Washington University

David Vogel, University of California, Berkeley

Aristide R. Zolberg, New School for Social Research, chair

\section{Heinz Eulau Award- $\$ 500$}

This award is for the best article published in The American Political Science Review in the previous year.

Kathie S. Golden, University of Colorado

David Laitin, University of Chicago, chair

Jack Nagel, University of Pennsylvania

Martin Shefter, Cornell University

Ralph J. Bunche Award- $\$ 500$

This award is for the best scholarly work in political science published in the previous year exploring the phenomenon of ethnic and cultural pluralism.

David Garrow, City University of New

York

Gwendolyn Mink, University of

California, Santa Cruz

Lorenzo Morris, Howard University
Gladys M. Kammerer Award- $\$ 1,000$

This award is for the best political science publication in that year in the field of U.S. national policy.

James S. Fleming, Rochester Institute of Technology

Jeanne T. Meadows, Spelman College

Alan Stone, University of Houston, chair

\section{Victoria Schuck Award- $\$ 500$}

This award is for the best book on women and politics published in the previous year.

Jo Freeman, Brooklyn

Isaac Kramnick, Cornell University, chair

Sonia Kruks, Oberlin College

Woodrow Wilson Foundation Award $-\$ 5,000$

This award is for the best book published in the U.S. that year on government, politics or international affairs.

Elinor Ostrom, Indiana University Adolph Reed, Jr., Yale University

Martin Schain, New York University, chair

\section{Carey McWilliams Award- $\$ 500$}

This award is given to recognize a journalist who has made a substantial contribution to our understanding of politics.

Glen Browder, U.S. House of Representatives

Scarlett G. Graham, Vanderbilt

University, chair

Donna Shalala, University of Wisconsin

\section{Hubert H. Humphrey Award- $\$ 500$}

This award is given in recognition of notable public service by a political scientist.

Xandra Kayden, Santa Monica, CA Jewel Prestage, Prairie View A\&M University, chair

Morton J. Tenzer, University of Connecticut

\section{John Gaus Lecture- $\$ 1,500$}

This award is to honor the recipient's lifetime of exemplary scholarship in the joint tradition of political science and public administration and, more generally, to recognize achievement and encourage scholarship in public administration.

Harry Bailey, Temple University

Jeane J. Kirkpatrick, Georgetown University

John Rohr, Virginia Polytechnic Institute and State University, chair
Benjamin E. Lippincott Award- $\$ 1,500$

This award is given every other year for a work of exceptional quality by a living political theorist that is still considered significant after a time span of at least 15 years since the original publication.

Amy Gutmann, Princeton University

Samuel P. Huntington, Harvard University

Arlene Saxonhouse, University of Michigan, chair

James Madison Award- $\$ 2,000$

This award is presented every three years to an American political scientist who has made a distinguished scholarly contribution to political science. The award will be presented next in 1993.

\section{APSA REPRESENTATIVES TO AFFILIATED ORGANIZATIONS}

American Association for the Advancement of Science (AAAS)Section $\mathrm{K}$

Term expiring February 12, 1992: James Thurber, American University

American Association for the Advancement of Slavic Studies (AAASS)

Charles Gati, Columbia University

American Council of

Learned Societies (ACLS)

Term expiring December 31, 1991:

Theodore J. Lowi, Cornell University

Consortium of Social Science Associations (COSSA)

Terms expiring December 31, 1993 .

Raymond E. Wolfinger, University of California, Berkeley

Catherine E. Rudder, American Political Science Association

Council of Professional Association on Federal Statistics (COPAFS)

Howard Silver, COSSA

Jack Katosh, Mathew Greenwald \& Associates

International Political Science Association (IPSA)

Terms expiring 1991:

Philip E. Converse, University of Michigan

Robert G. Gilpin, Princeton University

Robert Scalapino, University of

California, Berkeley

Social Science Research Council (SSRC)

Term expiring June 30, 1992: 
Suzanne Berger, Massachusetts Institute of Technology

\section{A Report on the Congressional Fellowship Program, 1989-90 and 1990-91}

The Congressional Fellowship Program is a professional level internship that gives academics, journalists, federal executives, and other professionals an opportunity to work on the staffs of senators, representatives, and congressional committees. Its goals are:

- to improve the quality of scholarship and teaching on Congress and American national politics;

- to enhance public understanding of Congress and policymaking; and

- to provide professionals from several fields with practical experience in Congress and insight into the legislative process.

Since 1953, the first year of the Program, there have been a total of 1,397 Fellows, including 225 political scientists, 184 journalists, 678 federal executives, and 284 medical faculty and others.

Although the first class of Fellows had only six members, in recent years the Program has grown to include between 40 and 50 Fellows each year. The political science and journalism Fellows are selected in nationwide competitions. Political science applicants must have completed their doctorates within the last fifteen years or be near completion, and reporters must have a bachelor's degree and between two and ten years of professional experience in newspaper, magazine, television, or radio reporting. Criteria for selection are quality training, demonstrated competence, maturity and responsibility, relevance of fellowship experience to career goals, and potential for professional advancement.

While the political scientists and journalists remain the core of the program and are supported by the APSA through contributions from corporations and foundations, the majority of each year's class of Fellows participates in the program through affiliate arrangements, including:

- federal executives (Grades 13-16) supported by agency training funds;

- Asian Fellows supported by the Asia Foundation;

- Health Policy Fellows, including medical faculty, supported by the Robert Wood Johnson Foundation;

- anthropology faculty supported by the
American Anthropological Association;

- West German Fellows supported by the German Marshall Fund;

- Carl Albert Fellows supported by the Carl Albert Center at the University of Oklahoma; and

- a French Fellow supported by the Fondation Franco-Americaine in Paris.

In recent years, those who have funded political scientists and journalists include the Knight Foundation, Knight Ridder, Incorporated, the Mary Norris Preyer Fund, the New York Times Company Foundation, MCI Communications Corporation, International Business Machines and the Poynter Fund.

The Walter and Phyllis Shorenstein Family has provided funding to endow a Fellowship in the name of their daughter, Joan Shorenstein Barone. Joan was a well-known and highly respected producer for CBS News who died in 1985 at a tragically early age. The Joan Shorenstein Barone Fellowship is awarded to a broadcast journalist of special merit, and was given for the first time to a $1986-87$ Fellow, Jean Powell, news reporter for KEZI-TV in Eugene, Oregon. The 1987 88 recipient was Jay A. Kohn, Capitol Bureau Chief, Montana Television Network, Helena, Montana. William Lewis Graf, State Capitol Reporter, WISC-TV, Madison, Wisconsin, was the recipient for 1988-89, and Philip L. Ingrassia, Assistant News Director and Legislative Reporter for KDLT-TV in Sioux Falls, South Dakota, was the recipient for 198990. Nick Beres, reporter for CBS affiliate KTVL-TV of Medford, Oregon, is the 1990-91 recipient.

The Poynter Fund contribution is designated to support a promising Fellow in print journalism. William D. Zaferos, political reporter for the Appleton PostCrescent, Appleton, Wisconsin, was named the Poynter Fellow for 1987-88. The first Poynter Fellow was Celia Cohen (1985-86), staff reporter for the Wilmington, Delaware News-Journal. Andrew Pollack, City Hall reporter for The Democrat and Chronicle Newspapers, Rochester, New York, was the 1986-87 recipient. The 1988-89 Poynter Fellow was Kenton Bird, editorial page editor, Idahonian/ Palouse Empire Daily News, Moscow, Idaho, and Pullman, Washington. Kristin Huckshorn, reporter for the San Jose Mercury News, California, was the 198990 Poynter Fellow, and Joseph Beck, state government reporter, Wisconsin State Journal, Madison, has been selected to be the 1990-91 Poynter Fellow.

The Fellowship Program commences in early November with an orientation period that includes meetings and semi- nars with members of Congress, congressional staffs, political scientists, journalists, lobbyists, government administrators, and others on a wide range of topics relating to Congress and national politics. During this time Fellows also begin exploring possibilities for assignments in congressional offices. These negotiations are conducted by the Fellows themselves, and their placements are decided by the Fellows and the offices in which they will work. Fellows begin work in House or Senate offices in early December, and serve in their initial assignments for about four and a half months. In April they are encouraged to look for new assignments on the other side of the legislature so that each Fellow has an opportunity to experience both the House and Senate during the Fellowship year. Seminars for the Fellows are held throughout the year to supplement the orientation period, and each Fellow also makes one trip with a Senator or Representative to the member's home state or district to observe constituent work and campaign activities.

Kay Sterling is Administrative Director of the Congressional Fellowship Program. Christopher J. Deering, Associate Dean, Columbian College, The George Washington University, is Director for Academic Planning and Development. An Advisory Committee, whose members are listed below, provides overall policy guidance for the Program.

\section{Congressional Fellowship Program} Advisory Committee

Thomas E. Mann, The Brookings Institution, Chairman

David S. Broder, Washington Post

Honorable Robert Dole, Senate Minority Leader

Honorable Thomas S. Foley, Speaker, U.S. House of Representatives

Honorable Bill Frenzel, former U.S.

Representative

David R. Gergen, U.S. News \& World Report

James F. Hoge, Jr., New York Daily News

Albert R. Hunt, Wall Street Journal

Neil Skene, Congressional Quarterly

Honorable Richard G. Lugar, U.S. Senate

Philip Meyer, University of North Carolina

Norman J. Ornstein, American Enterprise Institute

Leonard Parkinson, Atlantic Research Corp.

Honorable Richardson Preyer, Greensboro, North Carolina

Honorable David E. Price, U.S. House of Representatives

Cokie Roberts, National Public Radio

Robert Rosenzweig, Association of 